\title{
Functionalized C,N-Bipyrazole Receptor Grafted onto Silica Surface for Arsenic Adsorption and Its Antibacterial Activity
}

\section{Ahmad Abu Obaid1, Motasem Al-Masri1, Abdalhadi Deghles², Nagham Taha1, Shehdeh Jodeh1, Radi Smail ${ }^{3}$}

${ }^{1}$ An-Najah National University, Nablus, Palestine

${ }^{2}$ Al-Istiqlal University, Jericho, Palestine

${ }^{3}$ University Mohamed Premier, Oujda, Morocco

Email: obaid@najah.edu, sjodeh@najah.edu,daghlas2014@gmail.com,nouja.1990@hotmail.com, motasmm@najah.edu, radi_smaail@yahoo.fr

How to cite this paper: Obaid, A.A., Al-Masri, M., Deghles, A., Taha, N., Jodeh, S. and Smail, R. (2019) Functionalized C,N-Bipyrazole Receptor Grafted onto Silica Surface for Arsenic Adsorption and Its Antibacterial Activity. American Journal of Analytical Chemistry, 10, 38-53. https://doi.org/10.4236/ajac.2019.101004

Received: November 26, 2018

Accepted: January 25, 2019

Published: January 28, 2019

Copyright () 2019 by author(s) and Scientific Research Publishing Inc. This work is licensed under the Creative Commons Attribution International License (CC BY 4.0).

http://creativecommons.org/licenses/by/4.0/

Open Access

\begin{abstract}
The present study is based on the investigation of performance of C,N-bipyrazole receptor grafted onto silica surface (SG2P) of adsorption Arsenic (AS) from aqueous solutions. The effects of operating parameters that include $\mathrm{pH}$, contact time, concentration of As and dosage of adsorbent on adsorption were accomplished. The results clearly showed that the removal efficiency of As was decreased with an increasing of As concentration, $\mathrm{pH}$, and temperature, while it was continuously increasing with time and adsorbent dose. Moreover, the removal efficiency of $\mathrm{Cr}$ (VI) adsorption was $75 \%$ corresponding to $\mathrm{pH}$; temperature $\left({ }^{\circ} \mathrm{C}\right)$, initial concentration $(\mathrm{ppm})$ and weight of dose $(\mathrm{g})$ were 6,25 , and 0.04 respectively at 24 hours. The adsorption capacity of the synthesized sorbent (SG2P) for arsenic at $\mathrm{pH}<7$ from pseudo second order in batch experiments was efficient at 20 minutes. Furthermore, the results obtained in this study presented that the antimicrobial activity was limited where the Escherichia coli (ATCC25922) and Staphylococcus aureus (ATCC25932) were as a reference strains, while, the SG2P was able to inhibit growth only at high concentration $(\mathrm{MIC}=1.5625 \mathrm{mg} / \mathrm{ml})$.
\end{abstract}

\section{Keywords}

Antimicrobial Activity, Arsenic, Adsorption, Pseudo Second Order, Escherichia coli

\section{Introduction}

Arsenic (As) is the $20^{\text {th }}$ most abundant element present in the earth's crust; it is 
considered as a toxic trace element present in natural waters (ground and surface water), and has become a major unavoidable threat for the life of human beings and useful microorganisms. Arsenic concentration in soils and water can become high due to several reasons like, mineral dissolution, use of arsenical pesticides, disposal of fly ash, mine drainage, and geothermal discharge [1]. The major arsenic species present in natural waters are arsenate ions: $\mathrm{H}_{3} \mathrm{AsO}_{4}$, $\mathrm{H}_{2} \mathrm{AsO}_{4}^{-}, \mathrm{HAsO}_{4}^{2-}$, and $\mathrm{AsO}_{4}^{3-}$ (oxidation state $\mathrm{V}$ ) and arsenite ions, $\mathrm{H}_{3} \mathrm{AsO}^{3}$, $\mathrm{H}_{2} \mathrm{AsO}_{3}^{-}$and $\mathrm{HAsO}_{3}^{2-}$ (oxidation state III). However, $\mathrm{As}(\mathrm{V})$ ions are most widespread in oxygenated water while As(III) is found in anaerobic conditions like in well water or in groundwater. The concentration of arsenic species is mainly dependent on redox potentials [2] and $\mathrm{pH}$ [3].

Recently, the environmental fate and behavior of arsenic (As) are receiving increased attention due to the arsenic (As) pollution in groundwater. It has been a serious health threat to the human beings in the world. Occurrence of arsenic in groundwater above the permissible value $(>10 \mu \mathrm{g} / \mathrm{L} \mathrm{WHO})$ is one of the wide spread problem owing to its toxicity and carcinogenicity [4]. In natural waters arsenic normally occurs in the oxidation states +III (arsenite) and $+\mathrm{V}$ (arsenate). The removal of As(III) is more difficult than the removal of $\mathrm{As}(\mathrm{V})$. Thus, As(III) has to be oxidized to $\mathrm{As}(\mathrm{V})$ prior to its removal. In this context, Arsenic is considered as a toxic metal which is toxic to living organisms and harmful to the environment when it is directly discharged into water body. Arsenic can be easily absorbed by fishes and vegetables due to its high solubility in the aquatic environment and may be accumulate in the human body by the means of food chain. So, it is indispensable to treat water and/or wastewater containing toxic metals like arsenic to remove their adverse effects on human and ecology. Recently several methods of treating water for arsenic reduction are being investigated; such as ion-exchange, adsorption, chemical precipitation, membrane filtration, and flocculation and electrochemical methods [5]. Adsorption is a fundamental process in the physicochemical treatment of municipal wastewaters, a treatment which can economically meet today's higher effluent standards and water reuse requirements. Also, it considered as a broad spectrum of physical, biological, and chemical processes and operations in the environmental field. Purification of gases by adsorption has played a major role in air pollution control, and adsorption of dissolved impurities from solution has been widely employed for water purification. Adsorption is now viewed as a superior method for wastewater treatment and water reclamation [6] [7]. Based on literature reviews, so far, no other studies adsorption on new chemical adsorbent (C,N-bipyrazole with a 3-glycidoxyprpoyl-trimethoxyilane silylant agent) onto a silica surface in short (SG2P) have used. The objectives of this study were to prepare supported SG2P and to test its performance for arsenic removal from water. The effects of various parameters such as adsorbent dosage, $\mathrm{pH}$, contact time, concentration of As and temperature on arsenic removal were assessed. 


\section{Materials and Methods}

\subsection{Chemicals and Instruments}

The entire chemicals used were of AR grade and were used without further purification. All aqueous solutions were prepared in double distilled water. The distilled water was inspected for arsenic concentration. The concentration was lower than $10 \mathrm{ppb}$, the detection limit that can be easily accomplished by the analytical methods used in this study [8]. The permissible limit of arsenic is $10 \mathrm{ppb}$. Stock solutions of arsenic were prepared in reverse deionized (DI) water using arsenic trioxide. Arsenic working solutions were freshly prepared by diluting arsenic stock solutions with DI water. $\mathrm{H}_{2} \mathrm{SO}_{4}$ and $\mathrm{NaOH}(0.1 \mathrm{~N})$ were used for adjusting the $\mathrm{pH}$ of the arsenic solution. Then a calibration curve of absorbance versus concentration (Figure 1) was constructed at the time of analysis. Calibration coefficient $\left(R^{2}\right)$ was at least 0.983 for all analyses. Appropriately diluted solutions were made from the stock as and when required for calibration purpose.

The instruments used for the experimental work are Electronic Balance, $\mathrm{pH}$ meter; Spectrophotometer, Gutzeit apparatus, incubator and Gyro shaker which were used from the college laboratory and all the glass that used were made up of Borosilicate. On the other hand, the amount of metal ion that was sorbed and the percent removal of metal ion by adsorbent were calculated by applying Equation (1) and Equation (2) respectively:

$$
\begin{aligned}
q & =(C o-C f) \div . V \\
\text { \%Removal } & =(C o-C f) \div C o 100
\end{aligned}
$$

where $q$ is the amount of metal ion sorbed by the adsorbent $(\mathrm{mg} / \mathrm{g})$; $C o$ is the initial metal ion concentration; $(\mathrm{mg} / \mathrm{L}), C f$ is the final ion concentration $(\mathrm{mg} / \mathrm{L})$ after the chemo-sorption occurred, $V$ is the volume of aqueous solution (L) in contact with the adsorbent, and $\mathrm{m}$ is the mass $(\mathrm{g})$ of adsorbent.

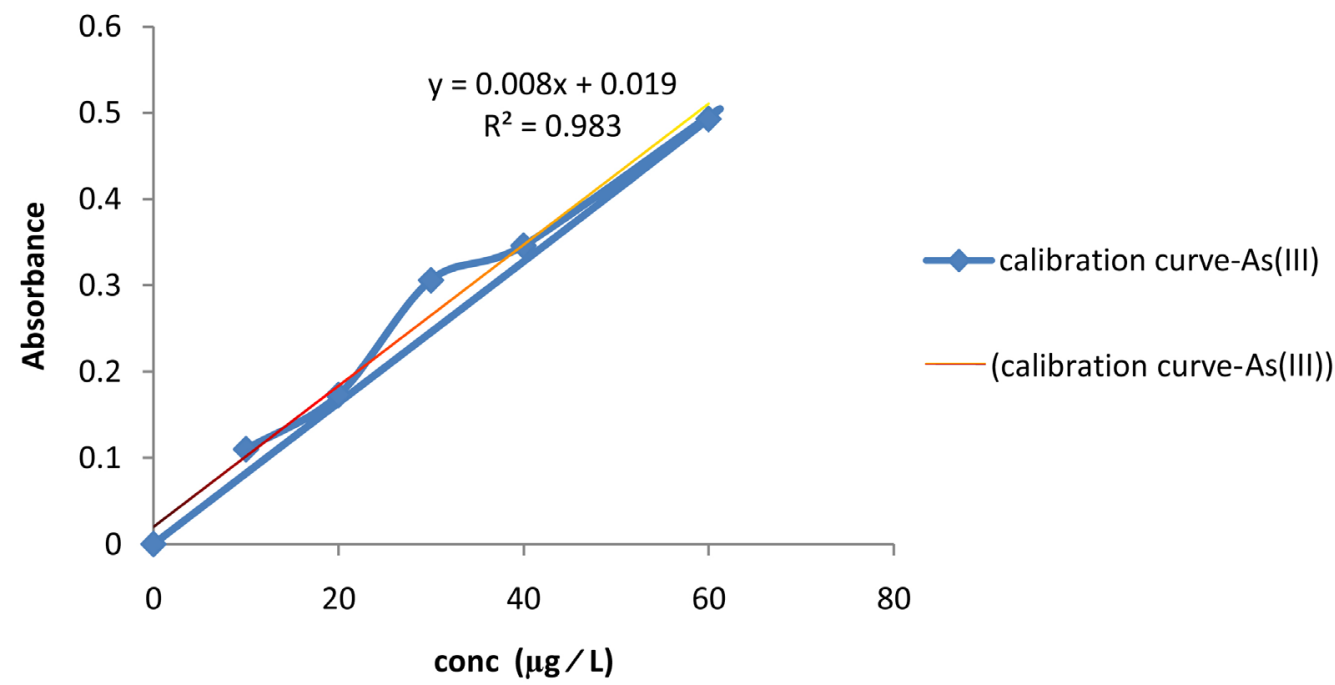

Figure 1. Linear calibration curve of absorbance vs. concentration for As (III) concentrations in the range $10-60 \mu \mathrm{g} / \mathrm{L}$. 


\subsection{Methods of Analysis}

\subsubsection{Preparation of Adsorbent Substance (SG2P)}

After converting the hydroxy-bipyrazolic ligand 4 to the alcoolate derivative using sodium metal in tetrahydrofuran, the resulting salt $(103 \mathrm{~mol})$ was added to a suspension of 3-glycidoxypropyl-functionalized silica (SiPz) $(1.00 \mathrm{~g})$ in $30 \mathrm{ml}$ of dimethylformamide (DMF). The mixture was stirred and refluxed under nitrogen for $24 \mathrm{~h}$. The solid material was filtered, and the residue was washed with DMF, toluene, water (distilled and deionized), methanol, dichloromethane (150 ml of each) and finally dried [9] [10].

\subsubsection{Determination of Optimum Dosage of Adsorbent}

To determine the optimum dosage of SG2P, it was added to the conical flask in different dosage varying from $(0.02 \mathrm{~g}, 0.04 \mathrm{~g}$, and $0.1 \mathrm{~g}$ up to $0.15 \mathrm{~g})$, containing $10 \mathrm{~mL}$ concentration of arsenic solution $(10 \mu \mathrm{g} / \mathrm{L})$ at $\mathrm{pH}$. The solution in the conical flask was subjected to stirring for optimum contact time, filtered and analyzed for residual arsenic concentration. The dosage which provides minimum residual concentration is chosen as optimum dosage.

\subsubsection{Selection of Optimum Contact Time}

The adsorption is strongly influenced by the contact time. To study the effect of contact time, $10 \mathrm{~mL}$ of $10 \mu \mathrm{g} / \mathrm{L}$ arsenic solution was mixed with $0.02 \mathrm{~g}$ of adsorbant (SG2P), stirred at different contact times varying from (5 mins, 15 mins up-to 180 mins). Then filtrate was analyzed for arsenic concentration using uv visible spectrophotometer.

\subsubsection{Selection of Optimum $\mathrm{pH}$ on Arsenic}

It was reported in prior studies that $\mathrm{pH}$ is a central factor that affects the performance of adsorption process. The effect of $\mathrm{pH}$ on arsenic adsorption was studied by performing equilibrium adsorption tests at different initial $\mathrm{pH}$ values. i.e. from 1.0 to 12.0. The $\mathrm{pH}$ of solution was adjusted by using $0.1 \mathrm{~N} \mathrm{H}_{2} \mathrm{SO}_{4}$ or $0.1 \mathrm{~N} \mathrm{NaOH}$. The $\mathrm{pH}$ which gives minimum residual concentration is chosen as optimum $\mathrm{pH}$.

\subsubsection{Determination of Optimum Temperature on Arsenic}

The effect of temperature was investigated at different degrees, $25^{\circ} \mathrm{C}, 35^{\circ} \mathrm{C}, 45^{\circ} \mathrm{C}$ and $55^{\circ} \mathrm{C}$. For each temperature, a $0.02 \mathrm{~g}$ adsorbent (SG2P) samples was added to $10 \mathrm{~mL}$ of $\mathrm{As}(\mathrm{III})$ solutions with concentration $10 \mu \mathrm{g} / \mathrm{L}$ at $\mathrm{pH}$ around 6 . The temperature which gives minimum residual concentration is chosen as optimum temperature.

\subsubsection{Selection of Optimum Initial Concentration of Arsenic}

$\mathrm{Al}$ of these concentrations of 10,20,30,40 and $60 \mathrm{ppb}$ solutions were prepared from the stock solution to find out the optimum concentration, $0.02 \mathrm{~g}$ of adsorbent (SG2P) was added to a number of tubes contains $10 \mathrm{ml}$ of the previous concentrations of $\mathrm{As}(\mathrm{III})$ solutions under optimized temperature $\left(25^{\circ} \mathrm{C}\right)$ and $\mathrm{pH}$ 6 for $30 \mathrm{~min}$, the absorbance of the solution above the solid residue was meas- 
ured by Flame Atomic Absorption at $193.7 \mathrm{~nm}$.

\subsubsection{Determination of Antibacterial Activity of Adsorbent} Substance (SG2P)

Antibacterial activity of SG2P was determined by broth micro-dilution method in which SG2P was serially diluted and examined against the bacteria. Minimum inhibitory concentration (MIC) was considered the lowest concentration of substance that inhibited visible growth of bacteria.

\section{Results and Discussions}

\subsection{Effect of Contact Time}

Effect of contact time was investigated and graph of percentage of arsenic removal versus time in minutes was schemed as shown in Figure 2. From the graph it is clear that the adsorption curves are characterized by sharp rise in removal efficiency of Arsenicat the first 20 minutes. Then it has negligible effect. This is may be due to accumulate of chromium ions at the surface of As(III). In this context, the optimum time for the adsorption of arsenic on SG2P was 20 minutes.

\subsection{Effect of Adsorbent Dosage}

Effect of adsorbent dosage was examined and graph of percentage of arsenic removal versus dosage was plotted as shown in Figure 3. From the graph it is observed that, as the dosage of SG2P increases, amount of arsenic decreases, sharply in the beginning and attains maximum later. This is mainly due to the large contact surface area and adsorption sites available for adsorption. The dosage, at which maximum removal is attained, is taken as maximum dosage. The removal efficiency on arsenic was found to be $77 \%, 80.5 \%$, and $81.5 \%$ with an optimum dosage of $0.05 \mathrm{~g}, 0.1 \mathrm{~g}$, and $0.15 \mathrm{~g}$ respectively.

\subsection{Effect of $\mathrm{pH}$}

The adsorption of arsenic from aqueous solution using GS2P in this research was found to be a lower $\mathrm{pH}(\mathrm{pH} 3)$ dependent process. The graph of percentage of arsenic removal versus $\mathrm{pH}$ was plotted as shown in Figure 4. From the graph it is observed that, arsenic is removed more effectively in slight acidic range.

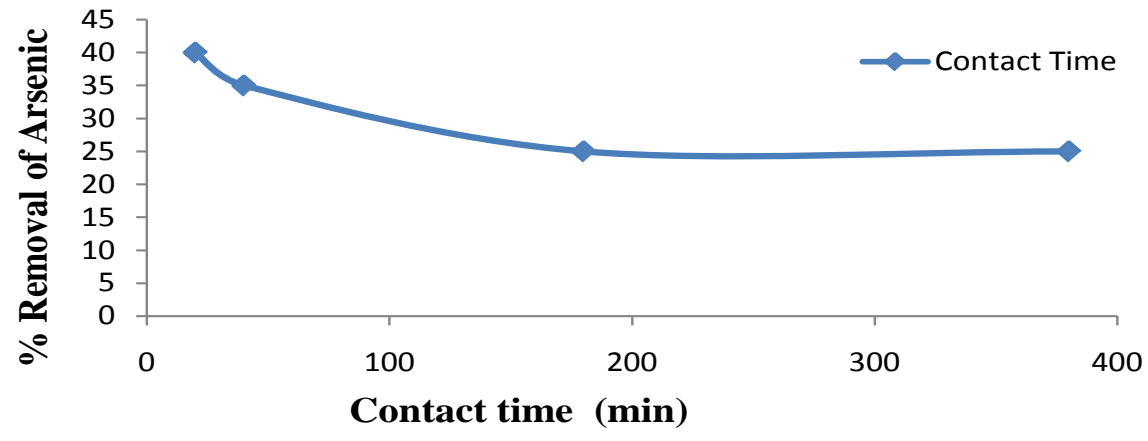

Figure 2. Effect of contact time. 


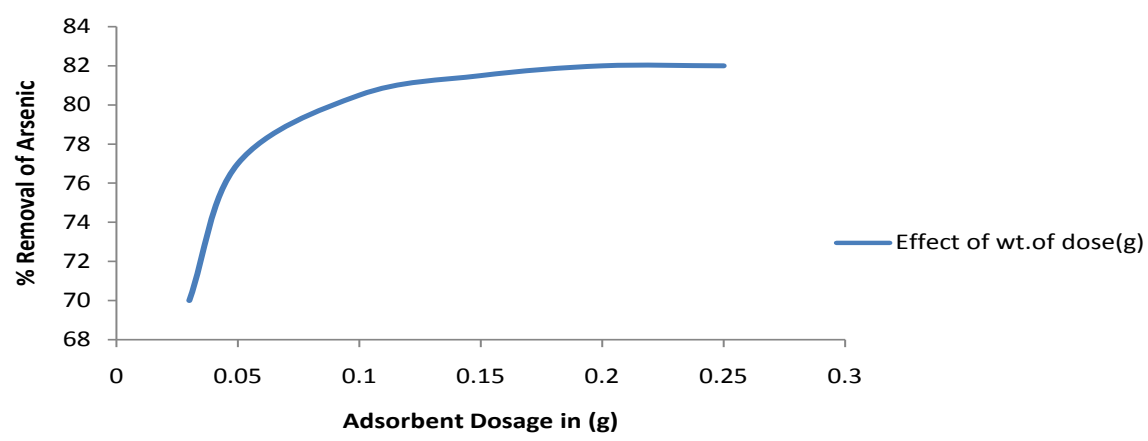

Figure 3. Effect of adsorbent dosage.

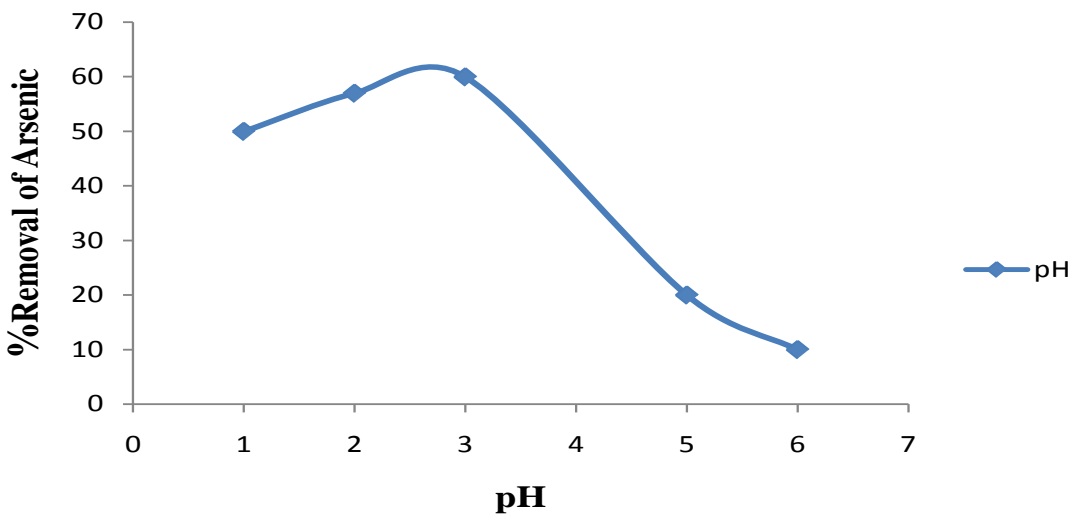

Figure 4. $\mathrm{pH}$ effect on $\mathrm{As}(\mathrm{III})$ adsorption $\left(C_{o}=10 \mu \mathrm{g} / \mathrm{L}, T=25^{\circ} \mathrm{C}\right.$, adsorbent dose $\left.=0.02 \mathrm{~g}\right)$.

This is because the solution contains protons that bind with electrons from oxygen, so the negative charge on the surface attract the positive ions of As, where at high $\mathrm{pH}$ in alkaline conditions the result showed is not favorable for arsenic sorption because carboxyl, hydroxyl, and amide groups of the adsorbent become negatively charged and a high density of $\mathrm{OH}^{-}$at alkaline conditions would compete with all anionic species of As(III) [11].

\subsection{Effect of Temperature}

Effect of temperature was investigated and graph of percentage of arsenic removal versus temperature was plotted as shown in Figure 5. From the graph it is observed that, arsenic is removed more effectively in high temperature range. As expected, increasing temperature will lead to increase in temperature results in increase in mobility of large metal ions, which indicates that the adsorption process is endothermic, leads to swelling effect within the internal structure of adsorbent that in turn, encourages the metal ions to penetrate further and increase in the kinetic energy of adsorbent particles that increase the collision between adsorbent and adsorbate molecules results in enhancing the removal of metals from adsorbent surface [12].

\subsection{Effect of Arsenic Concentration}

The effect of arsenic concentration on the adsorption was studied under optimized 


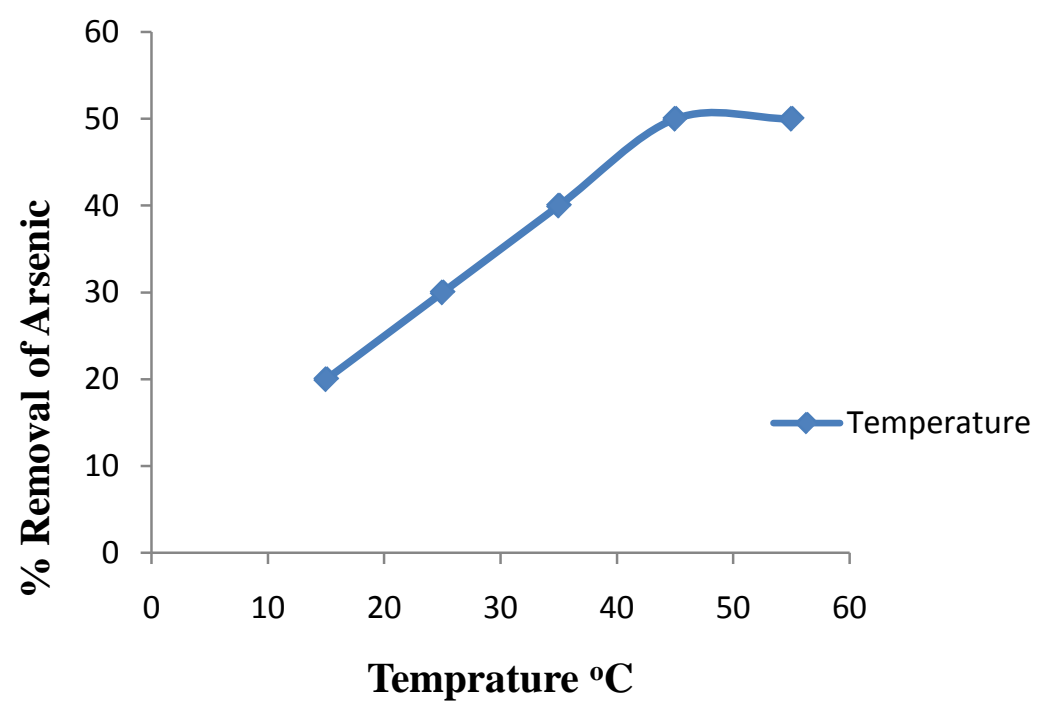

Figure 5. Effect of temperature on As(III) adsorption $\left(C_{o}=10 \mathrm{mg} / \mathrm{L}\right.$, time $=60 \mathrm{~min}$, adsorbent dose $=0.02 \mathrm{gm}$ ).

$\mathrm{pH}$ found from our previous results. Concentrations of Arsenic varied from 10 $40 \mathrm{ppb} .10 \mathrm{ml}$ of each concentration of arsenic was treated with the adsorbent at $\mathrm{pH}$ value of 3.0. The results are illustrated in Figure 6, which show GS2P is more efficient adsorbent at low concentrations of arsenic. Because at the beginning the removal of As(III) ions is high due to large surface area of adsorbent and when the saturation point is reached, at equilibrium the capacity of the (SG2P) to adsorb As(III) ions is controlled and the ions transported from the exterior to the interior sites of the (SG2P) particles [13].

\subsection{Adsorption Isotherm of Arsenic}

Adsorption isotherms are used to explain the equilibrium of metal ions that occurs between the solid phase of adsorbent and the aqueous solution. Freundlich and Langmuir isotherms are the most models that widely used to determine some kinetic and thermodynamic parameters that can give a clearer image about the binding mechanism.

\subsubsection{Freundlich Adsorption Isotherm}

The Freundlich isotherm is an empirical equation employed to describe heterogeneous systems. This model is specified with the following equation [14]:

$$
Q_{e}=K_{F} C_{e}^{1 / n}
$$

The linear form of this equation can be written as:

$$
\ln Q_{e}=\frac{1}{n} \ln C_{e}+\ln K_{F}
$$

where, $K_{F}$ and $n$ are Freundlich constants with $K_{F}$ is an approximate indicator of adsorption capacity of the sorbent and $n$ giving an indication of how favorable the adsorption process. The magnitude of the exponent, $1 / n$, gives an indication of the favorability of adsorption. If value of $1 / n$ is below one, it indicates a normal 


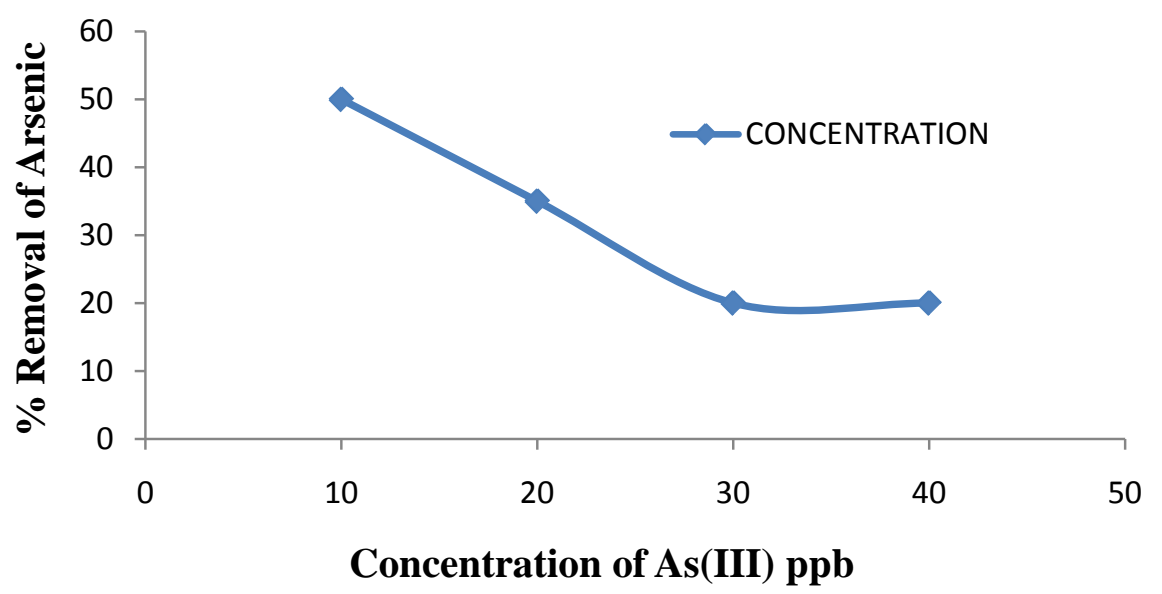

Figure 6. Effect of As(III) concentration on adsorption.

adsorption. If $n$ lies between one and ten, this indicates a favorable sorption process [15]. To determine the constants $K_{F}$ and $n$, the linear form of the equation may be used to produce a graph of $\ln \left(Q_{e}\right)$ against $\ln \left(C_{e}\right)$ as shown in Figure 7.

From Table 1 the values of $n=1.6949$ and $1 / n=0.59$, as Freundlich isotherm model, these values indicate that the sorption of As(III) on SG2P is favorable and the $R^{2}$ value is 0.911 .

\subsubsection{Langmuir Adsorption Isotherm}

This describes quantitatively the formation of a monolayer adsorbate on the outer surface of the adsorbent, and after that no further adsorption takes place. Thereby, the Langmuir represents the equilibrium distribution of MB dye between the solid and liquid phases. The Langmuir isotherm is valid for monolayer adsorption onto a surface containing a finite number of identical sites. The model assumes uniform energies of adsorption onto the surface and no transmigration of adsorbate in the plane of the surface. Based upon these assumptions, Langmuir represented the following equation [14] [16]:

$$
\frac{C_{e}}{Q_{e}}=\frac{1}{Q_{m}} C_{e}+\frac{1}{Q_{m} K_{L}}
$$

where:

$C_{e}=$ the equilibrium concentration of adsorbate $(\mathrm{mg} / \mathrm{L})$;

$Q_{e}=$ the amount of As(III) adsorbed per gram of the adsorbent ( $\left.\mathrm{mg} / \mathrm{g}\right)$;

$Q_{m}=$ maximum monolayer coverage capacity $(\mathrm{mg} / \mathrm{g})$;

$K_{L}=$ Langmuir isotherm constant $(\mathrm{L} / \mathrm{mg})$.

The values of $Q_{m}$ and $K_{L}$ were computed from the slope and intercept of the Langmuir plot of $C_{e} / Q_{e}$ versus $C_{e^{*}}$ From Langmuir plots which is shown in Figure 8. amount adsorbed for monolayer formation $\left(Q_{m}\right)$, Langmuir adsorption-desorption equilibrium constant $\left(K_{L}\right)$ and regression constant $\left(R^{2}\right)$ were determined and values are shown in Table 2.

The essential characteristics of the Langmuir isotherm can be expressed in 


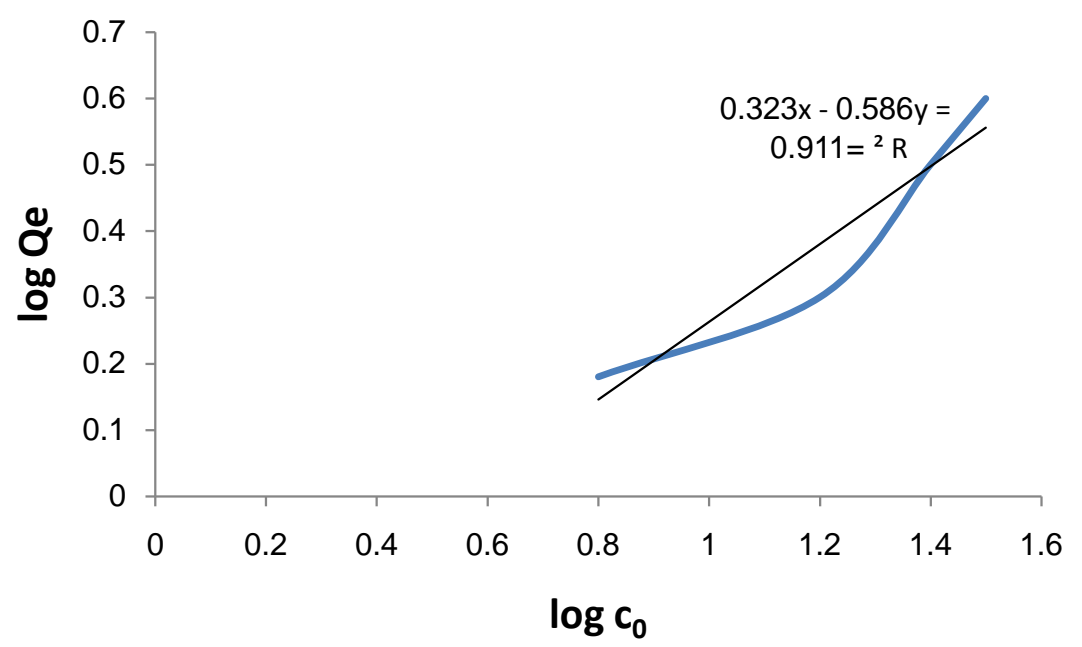

Figure 7. Freundlich plot for As(III) adsorption on (SG2P).

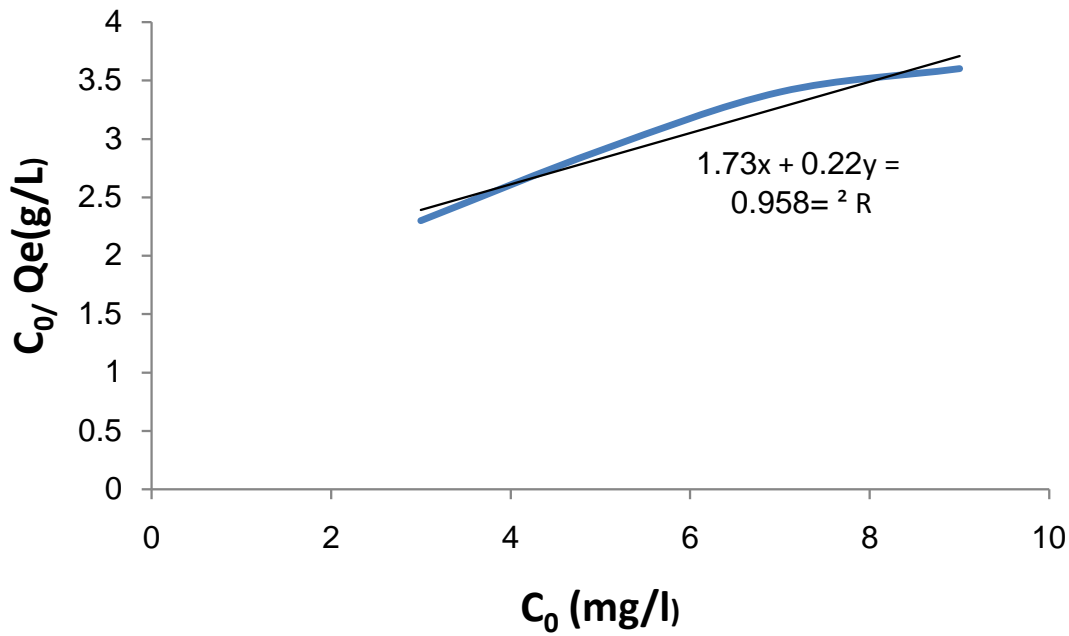

Figure 8. Langmuir plot for As(III) adsorption on (SG2P).

Table 1. Parameters and correlation coefficient of Freundlich isotherm model for adsorption of As(III) onto SG2P.

\begin{tabular}{|c|c|c|c|c|}
\hline \multicolumn{5}{|c|}{ Freundlich isotherm model parameters } \\
\hline \multirow[b]{2}{*}{ Adsorbate } & \multicolumn{4}{|c|}{ Parameters } \\
\hline & $\frac{1}{n}$ & $n$ & $K_{F}=(\mathrm{mg} / \mathrm{g})$ & $R^{2}$ \\
\hline SG2P & 0.59 & 1.6949 & 2.1 & 0.911 \\
\hline
\end{tabular}

Table 2. Parameters and correlation coefficient of Langmuir isotherm model for adsorption of As(III) onto (SG2P).

\begin{tabular}{ccccc}
\hline \multicolumn{5}{c}{ Langmuir isotherm model parameters } \\
Adsorbate & $Q_{m}(\mathrm{mg} / \mathrm{g})$ & $K_{L}=(\mathrm{L} / \mathrm{mg})$ & $R_{L}$ Parameters & $R^{2}$ \\
& 4.61 & 0.578 & 0.166 & 0.958 \\
\hline
\end{tabular}


terms of a dimensionless constant separation factor $R_{L}$ that is given by the following equation [15]:

$$
R_{L}=\frac{1}{\left(1+K_{L} C_{o}\right)}
$$

where, $C_{o}$ is the highest initial concentration of adsorbate $(\mathrm{mg} / \mathrm{L})$.

The value of $R_{L}$ indicates the shape of the isotherm to be either unfavorable $\left(R_{L}>1\right)$, linear $\left(R_{L}=1\right)$, favorable $\left(0<R_{L}<1\right)$, or irreversible $\left(R_{L}=0\right)$. The $R_{L}$ values between 0 and 1 indicate favorable adsorption. The value of $R_{L}$ in the present investigation was found to be 0.166 at $25^{\circ} \mathrm{C}$ indicating that the adsorption of As(III) dye on (SG2P) is favorable [17].

\subsection{Rate Order of the Adsorption Process}

Uptake of each metal ion from different initial concentrations of the metal can be used to study the dependency of the rate of adsorption on the concentration of metal ion left in solution. Thus, the reaction order of the adsorption process can be determined. Pseudo first-order equation was applied for evaluation the adsorption kinetics for As(III) onto SG2P, the rate constant for the adsorption $K_{1}$ was evaluated. The pseudo first-order equation expressed as Equation (4):

$$
\log \left(Q_{e}-Q_{t}\right)=\log Q_{e}-\left(\frac{K_{1}}{2.303}\right) t
$$

where $Q_{e}$ is the adsorption capacity of the SG2P at equilibrium $(\mathrm{mg} / \mathrm{g}), Q_{t}$ is the amount of $\mathrm{As}(\mathrm{III})$ adsorbed at time $t(\mathrm{mg} / \mathrm{g})$ and $K_{1}$ is the pseudo first order rate constant $\left(\mathrm{min}^{-1}\right)$.

A linear plot of $\log \left(Q_{e}-Q_{t}\right)$ against time allows obtaining the rate constant (Figure 9). If the plot was found to be linear with good correlation coefficient, indicating that Lagergren's equation is appropriate to As(III) sorption on SG2P so the adsorption process is a pseudo first order process. The Lagergren's first order rate constant $\left(K_{1}\right)$ and $Q_{e}$ determined from the model are presented in $\mathrm{Ta}$ ble 3 along with the corresponding correlation coefficients. It was observed that the pseudo first order model did not fit well. It was found that the calculated $Q_{e}$ values do not agree with the experimental $Q_{e}$ value This suggests that the adsorption of As(III) does not follow first-order kinetics.

From Figure 9, the $R^{2}$ value shows that the adsorption As(III) onto SG2P does not obey the pseudo first-order kinetics, and the pseudo first-order model is not appropriate for the adsorption.

The Lagergren pseudo first-order rate constant $\left(K_{1}\right)$ and $\left(Q_{e}\right)$ values are represented in Table 3.

The pseudo second order kinetics may be expressed in a linear form as integrated second order rate law [13]:

$$
\frac{t}{Q_{t}}=\frac{1}{Q_{e}} t+\frac{1}{K_{2} Q_{e}^{2}}
$$

where $K_{2}$ is the pseudo second order rate constant $\left(\mathrm{g} \cdot \mathrm{mg}^{-1} \cdot \mathrm{min}^{-1}\right)$. 


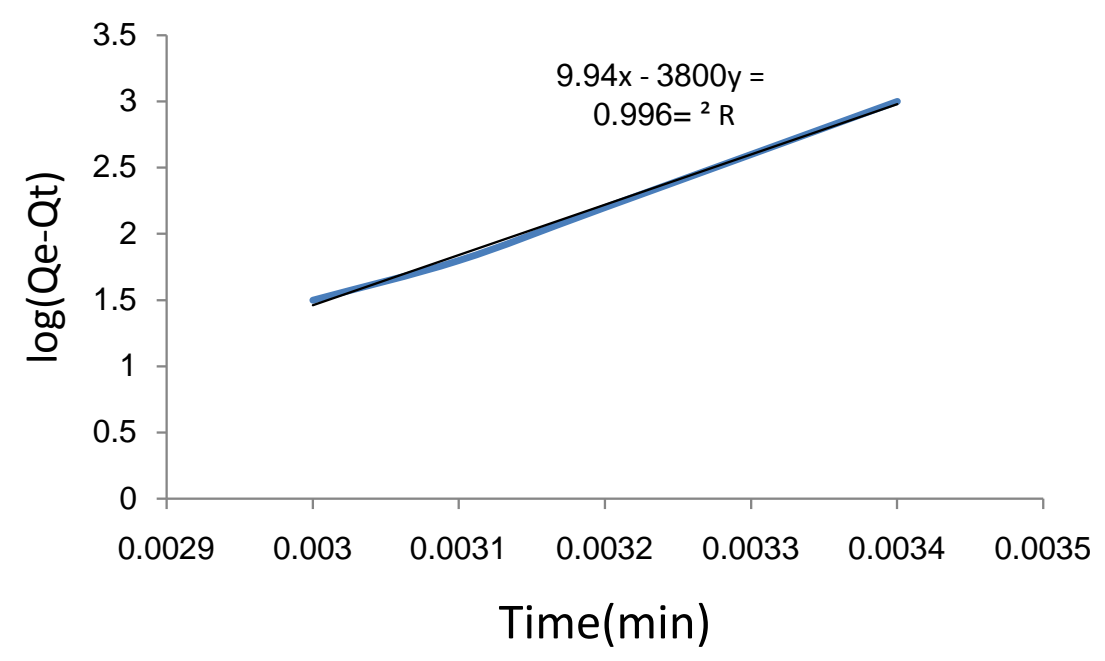

Figure 9. Pseudo first-order adsorption kinetics of As(III) onto (SG2P).

Table 3. Pseudo first-order parameters for As(III) adsorption onto SG2P at $25^{\circ} \mathrm{C}$.

\begin{tabular}{ccccc}
\hline & & \multicolumn{3}{c}{ pseudo first-order } \\
\cline { 3 - 5 } Adsorbent & $\begin{array}{c}Q_{e}(\exp ) \\
(\mathrm{mg} / \mathrm{g})\end{array}$ & $\begin{array}{c}K_{1} \\
\mathrm{~min}^{-1}\end{array}$ & $\begin{array}{c}\left.Q_{e} \text { (calculated }\right) \\
(\mathrm{mg} / \mathrm{g})\end{array}$ & $R^{2}$ \\
\hline SG2P & 2.3 & $4.6 \times 10^{-\mathrm{s}}$ & 0.51 & 0.408 \\
\hline
\end{tabular}

Pseudo second-order adsorption model for As(III) adsorption onto SG2P was applied and the rate constant for the adsorption $K_{2}$ was evaluated as shown in Figure 10.

The results obtained shows that the value of linear regression coefficient $R^{2}$ is 0.999 , the values of $Q_{e}$ experimental, $K_{2}, R^{2}$ and $Q_{e}$ calculated were listed in Table 4.

The results shows that the Pseudo second-order kinetic model perfect fit with experimental data and the value of $R^{2}=0.9998$, by comparing $\left(Q_{e}\right)$ experimental and $\left(Q_{e}\right)$ calculated values from Table 4 , there is agreement between experimental and calculated values for pseudo second order model, and $K_{2}$ value greater than $K_{1}$ value, so the pseudo second order model is favorable model for As(III) adsorption onto SG2P.

\subsection{Adsorption Thermodynamics}

Adsorption thermodynamics were determined using the thermodynamic equilibrium coefficients obtained at different temperatures and concentrations to verify possible adsorption mechanisms. The adsorption characteristics of a material can be expressed in terms of thermodynamic parameters such as $\Delta G$ (Gibbs free energy change), which can be calculated by the following equation [17]:

$$
\Delta G=-R T \ln K_{d}
$$

where $K_{d}$ is the thermodynamic equilibrium constant $\left(\mathrm{L} \cdot \mathrm{g}^{-1}\right)$.

According to thermodynamics, the Gibbs free energy is the difference between 


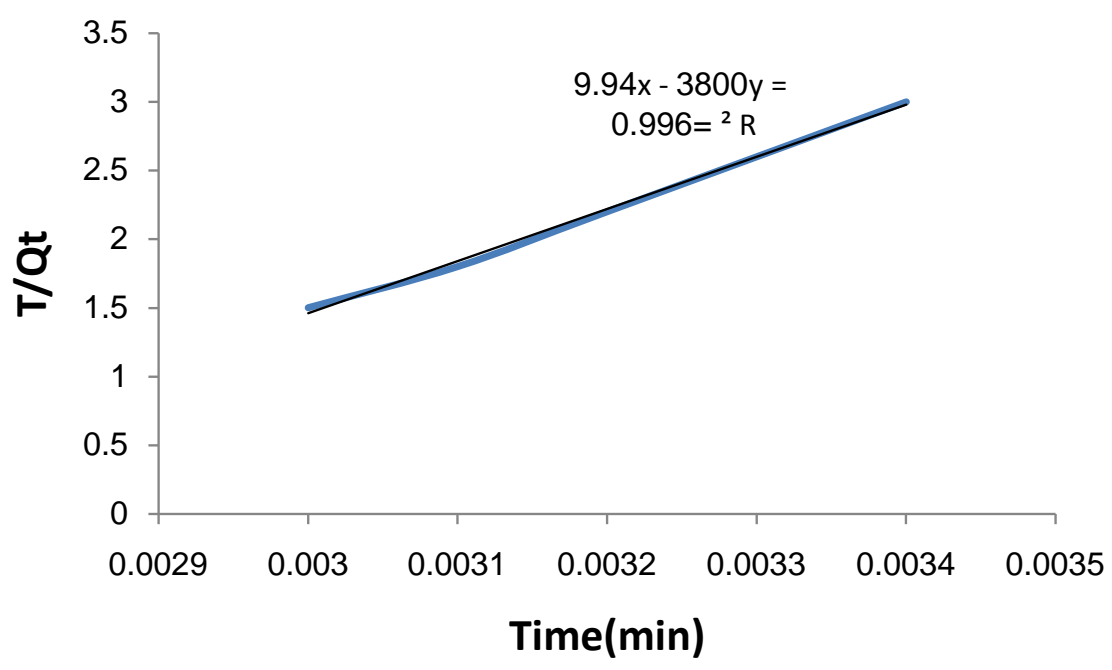

Figure 10. Pseudo second order adsorption kinetics of As(III) onto (SG2P).

Table 4. Pseudo second-order parameters for As(III) adsorption onto SG2P at $25^{\circ} \mathrm{C}$.

\begin{tabular}{ccccc}
\hline \multirow{2}{*}{ Adsorbent } & $\begin{array}{c}Q_{e}(\mathrm{exp}) \\
(\mathrm{mg} / \mathrm{g})\end{array}$ & $\begin{array}{c}K_{2} \\
\mathrm{~min}^{-1}\end{array}$ & $\begin{array}{c}\left.Q_{e} \text { (calculated }\right) \\
(\mathrm{mg} / \mathrm{g})\end{array}$ & $R^{2}$ \\
\hline SG2P & 2.3 & $171.1 \times 10^{-\mathrm{s}}$ & 2.1 & 0.9998 \\
\hline
\end{tabular}

the adsorption enthalpy $(\Delta H)$ and adsorption entropy $(\Delta S)$ multiplied by the temperature. In this manner, by applying this concept to Equation (9), the thermo chemical parameters $\Delta H$ and $\Delta S$ can be determined using Van't Hoff's plot (Figure 11), according to Equation (12) [18]:

$$
\ln K_{d}=-\frac{\Delta H}{R T}+\frac{\Delta S}{R}
$$

$\Delta H^{\circ}$ and $\Delta S^{\circ}$ were calculated from the slope and intercept of the linear plot of $\ln K_{d}$ versus $1 / T$ respectively. The results show that the enthalpy of adsorption $\Delta H^{\circ}$ was $-3.7886 \mathrm{~kJ} \cdot \mathrm{mol}^{-1}$ and $\Delta S^{\circ}$ was $9.9 \mathrm{~J} \cdot \mathrm{mol}^{-1} \cdot \mathrm{K}^{-1} . \Delta G^{\circ}$ was calculated at different temperatures from the following equation:

$$
\Delta G^{\circ}=\Delta H^{\circ}-T \Delta S^{\circ}
$$

The obtained thermodynamic values are given in Table 5 .

The negative $\Delta G^{\circ}$ values indicate that the adsorption is spontaneous at these temperatures. The negative value of $\Delta H^{\circ}$ reflects an exothermic adsorption and indicates that the adsorption is favored at low temperature. In the other hand, the positive value of $\Delta S^{\circ}$ suggests that some structural changes occur on the adsorbent and the randomness at the solid/liquid interface in the adsorption system increases during the adsorption process.

\subsection{Antibacterial Activity of SG2P}

The results of the minimum inhibitory concentration of micro dilution tray of the examined microorganism are shown in Figure 12 and in Table 6. 


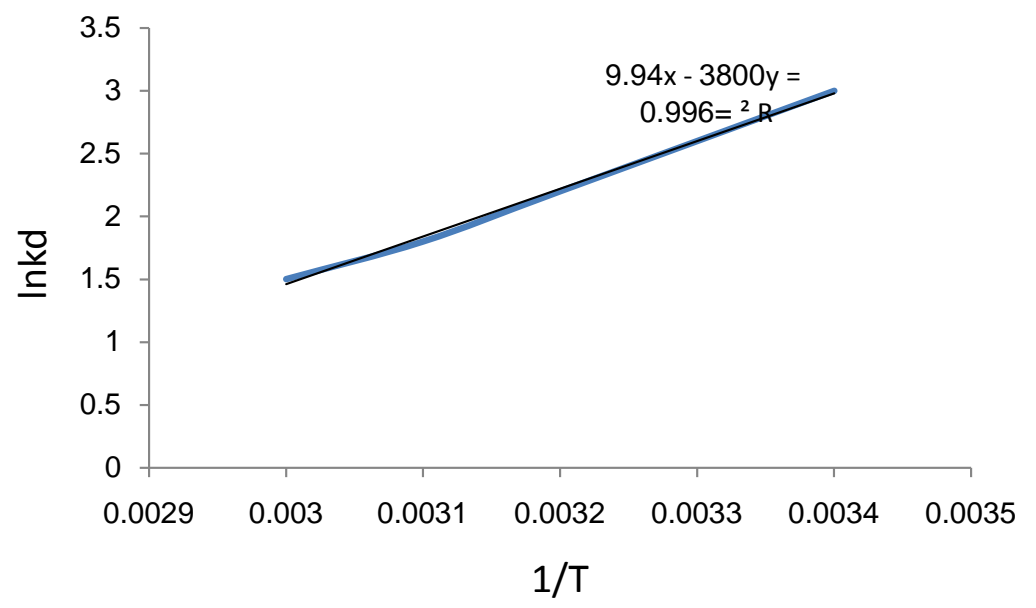

Figure 11. Plot of $\ln K_{d}$ versus $1 / T$ for As(III) adsorption on (SG2P).

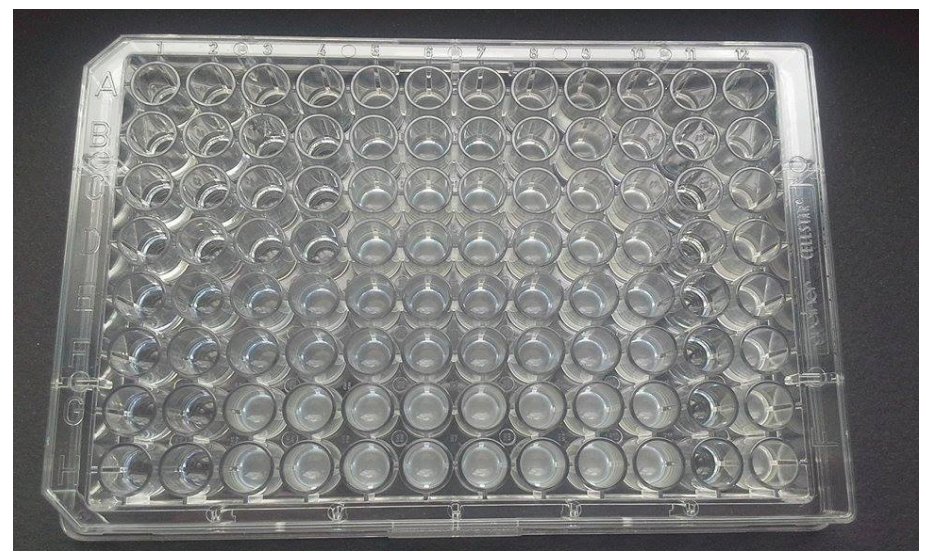

Figure 12 . The inhibitory activity of SG2P against $E$. coli and $S$. aureus.

Table 5. The values of the thermodynamic of As(III) adsorption at various temperatures.

\begin{tabular}{ccccccc}
\hline & \multirow{3}{*}{$\begin{array}{c}\Delta H^{\circ} \\
\text { Adsorbent }\end{array}$} & $\Delta S^{\circ}$ & \multicolumn{4}{c}{$\Delta G^{\circ}$} \\
\cline { 4 - 7 } & $(\mathrm{KJ} / \mathrm{mol})$ & $(\mathrm{J} / \mathrm{mol} \cdot \mathrm{K})$ & $289 \mathrm{~K}$ & $308 \mathrm{~K}$ & $318 \mathrm{~K}$ & $328 \mathrm{~K}$ \\
\hline \multirow{2}{*}{ SG2P } & -3.7886 & 9.9 & -6.6 & -6.8 & -6.9 & -7.0 \\
\hline
\end{tabular}

Table 6. Demonstration of bacterial growth and inhibition of growth by SG2P in each well.

\begin{tabular}{|c|c|c|c|c|c|c|c|c|c|c|c|c|c|}
\hline substance & & 1 & 2 & 3 & 4 & 5 & 6 & 7 & 8 & 9 & 10 & 11 & 12 \\
\hline S. aureus $+25 \mathrm{mg} / \mathrm{ml}$ of SG2P & A & - & - & - & - & + & + & + & + & + & + & - & + \\
\hline S. aureus $+25 \mathrm{mg} / \mathrm{ml}$ of SG2P & $\mathrm{B}$ & - & - & - & - & + & + & + & + & + & + & - & + \\
\hline E. coli $+25 \mathrm{mg} / \mathrm{ml}$ of SG2P & $\mathrm{C}$ & - & - & - & - & + & + & + & + & + & + & - & + \\
\hline E. coli $+25 \mathrm{mg} / \mathrm{ml}$ of SG2P & $\mathrm{D}$ & - & - & - & - & + & + & + & + & + & + & - & + \\
\hline S. aureus & $\mathrm{E}$ & - & - & + & + & + & + & + & + & + & + & - & + \\
\hline S. aureus & $\mathrm{F}$ & - & - & + & + & + & + & + & + & + & + & - & + \\
\hline E. coli & G & - & - & + & + & + & + & + & + & + & + & - & + \\
\hline E. coli & $\mathrm{H}$ & - & - & + & + & + & + & + & + & + & + & - & + \\
\hline
\end{tabular}

Abbreviation: -, no visible bacterial growth; +, visible bacterial growth. 
As shown in Figure 12, wells in column number 1,2, 11 and part of 3 and 4 possessed clear broth which indicated absence of bacterial growth (growth inhibition) or inoculation (well 11). On the other hand, wells with turbid broth indicated growth of bacteria due to absence of inhibition of DMSO or SG2P as in positive control of bacterial growth (well 12).

To well number 1 in the first four rows (A, B, C, D), $100 \mu \mathrm{l}$ of $25 \mathrm{mg} / \mathrm{ml} \mathrm{ad}$ sorbent (SG2P) dissolved in 50\% DMSO was add, thus this well contained $12.5 \%$ of adsorbent (SG2P). This was further serially diluted as described in materials and method section. On the other hand, to the first well (number 1) in the remaining four rows (E, F, G, H) $100 \mu \mathrm{l}$ of 50\% DMSO was added and a serial dilution of DMSO was prepared to detect antibacterial activity of DMSO and to ensure that the bacterial growth inhibition was due to SG2P and not DMSO.

The results shown in Figure 12, indicate that the inhibition of both of $E$. coli and $S$. aureus growth occurred in the first four wells containing SG2P concentration of $12.5,6.25,3.125$ and $1.5625 \mathrm{mg} / \mathrm{ml}$, so the minimum inhibition concentration of SG2P was $1.5625 \mathrm{mg} / \mathrm{ml}$. On the other hand, DMSO inhibited growth of $E$. coli and $S$. aureus in the first two wells (25\% and $12.5 \%)$ and did not show any antibacterial activity in wells number 3 and 4 in which SG2P showed antibacterial activity. These results indicated that SG2P possessed antibacterial activity against examined bacteria.

\section{Conclusion}

According to the results obtained in this study, the adsorption capacity of arsenic onto SG2P was efficient. We can be concluded that the removal efficiency of arsenic from aqueous solution has related robustly to operating parameters. The optimum adsorption capacity of arsenic was $50 \%$ at $\mathrm{pH} 5.0$, initial concentration $10 \mu \mathrm{g} / \mathrm{L}$, temperature of $35^{\circ} \mathrm{C}-40^{\circ} \mathrm{C}$ and contact time 20 minutes. The adsorption isotherms of arsenic were Freundlich model parameters value $1 / n$ and $n$, showing that the adsorption of As(III) onto SG2P is promising. While, Lagergren pseudo second order model has been applied to obtain the amount of As(III) adsorbed per unit mass of SG2P, the qe (cal.) was agreement with the experimental value qe (exp.), which explains the exchange between adsorbent and adsorbate. Regarding to antimicrobial activity, SG2P has a low antibacterial activity against both Staphylococcus aureus, and Escherichia coli. In this paper, we have proposed that it is possible to investigate more studies to explain the adsorption of toxic heavy metals as well as antimicrobial activity onto silica gel compound.

\section{Conflicts of Interest}

The authors declare no conflicts of interest regarding the publication of this paper.

\section{References}

[1] Guan, X.H., Wang, J. and Chusuei, C.C. (2008) Removal of Arsenic from Water 
Using Granular Ferric Hydroxide: Macroscopic and Microscopic Studies. Journal of Hazardous Materials, 156, 178-185. https://doi.org/10.1016/j.jhazmat.2007.12.012

[2] Ahn, J.S., Chon, C.M., Moon, H.S. and Kim, K.W. (2003) Arsenic Removal Using Steel Manufacturing Byproducts as Permeablereactive Materials in Mine Tailing Containment Systems. Water Research, 37, 2478-2488. https://doi.org/10.1016/S0043-1354(02)00637-1

[3] Korngold, E., Belayev, N. and Aronov, L. (2001) Removal of Arsenic from Drinking Water by Anion Exchange. Desalination, 141, 81-84. https://doi.org/10.1016/S0011-9164(01)00391-5

[4] World Health Organization (WHO) (2006) Guidelines for Drinking Water Quality. Vol. 1, 306.

[5] Fu, F.L. and Wang, Q. (2011) Removal of Heavy Metal Ions from Wastewater: A Review. Journal of Environmental Management, 92, 407-418. https://doi.org/10.1016/j.jenvman.2010.11.011

[6] Lo, S.L., Jeng, H.T. and Lai, C.H., (1997) Characteristics and Adsorption Properties of an Ironcoated Sand. Water Science \& Technology, 35, 63-70. https://doi.org/10.2166/wst.1997.0261

[7] Shen, Y.S. (1973) Study of Arsenic Removal from Drinking Water. Journal-American Water Works Association, 65, 543-548. https://doi.org/10.1002/j.1551-8833.1973.tb01892.x

[8] Worch, E. (2012) Adsorption Technology in Water Treatment-Fundamentals, Processes, and Modeling, Germany. Walter de Gruyter, GmbH \& Co. KG, Berlin, 345 p. https://doi.org/10.1515/9783110240238

[9] Radi, S., Attayibat, A., El-Massaoudi, M., Bacquet, M., Jodeh, SH., Warad, I., Salim S., Al-Showiman, S.S. and Mabkhot, Y.N. (2015) C,N-Bipyrazole Receptor Grafted onto a Porous Silica Surface as a Novel Adsorbent-Based Polymer Hybrid. Talanta, 143, 1-6. https://doi.org/10.1016/j.talanta.2015.04.060

[10] Radi, S., Attayibat, A., Ramdani, A. and Bacquet, M. (2008) Synthesis and Characterization of Novel Silica Gel Supported N-Pyrazole Ligand for Selective Elimination of $\mathrm{Hg}(\mathrm{II})$. European Polymer Journal, 44, 3163-3168. https://doi.org/10.1016/j.eurpolymj.2008.07.021

[11] Tiwari, S.K. and Pandey, V.K. (2013) Removal of Arsenic from Drinking Water by Precipitation and Adsorption or Cementation: An Environmental Prospective. Scienceflora, 5, 88-91.

[12] Attinti, R., Sarkar, D., Barrett, K.R., et al. (2015) Adsorption of Arsenic(V) from Aqueous Solutions by Goethite/Silica Nanocomposite. International Journal of Environmental Science and Technology, 12, 3905-3914. https://doi.org/10.1007/s13762-015-0902-2

[13] Egger, S., Lehmann, R.P., Height, M.J., Lossener, M.J. and Schuppler, M. (2009) Antimicrobial Properties of a Novel Silver-Silica Nanocomposite Material. Applied and Environmental Microbiology, 75, 2973-2976. https://doi.org/10.1128/AEM.01658-08

[14] Solomon, G. and Anagho, F. (2013) Equilibrium, Kinetic and Thermodynamic Studies of Research Library. Der Chemica Sinica, 4, 58-68.

[15] Yao, S., Liu, Z. and Shi, Z. (2014) Arsenic Removal from Aqueous Solutions by Adsorption onto Iron Oxide/Activated Carbon Magnetic Composite. Journal of Environmental Health, 12, 2-8.

[16] Hameed, B.H., Mahmoud, D.K. and Ahmad, AL. (2008) Equilibrium Modeling and 
Kinetic Studies on the Adsorption of Basic Dye by a Low-Cost Adsorbent: Coconut (Cocosnucifera) Bunch Waste. Journal of Hazardous Materials, 158, 65-72. https://doi.org/10.1016/j.jhazmat.2008.01.034

[17] Kubilay, S., Gürkan, R., Savran, A. and Sahan, T., (2007) Removal of Cu(II), Zn(II) and $\mathrm{Co}(\mathrm{II})$ Ions from Aqueous Solutions by Adsorption onto Natural Bentonite. Adsorption, 13, 41-51. https://doi.org/10.1007/s10450-007-9003-y

[18] Umoren, S.A., Etim, U.J. and Israel, A.U. (2013) Adsorption of Methylene Blue from Industrial Effluent Using Poly Vinyl Alcohol. Journal of Materials and Environmental Science, 4, 75-86. 